\title{
Urgensi Penyerapan Nilai Hukum Islam dan Hukum Adat dalam Pengaturan Tindak Pidana Perzinaan
}

\author{
Usman $^{\star}$, Sri Rahayu ${ }^{\star \star}$, Elizabeth Siregar ${ }^{\star \star \star}$ \\ $\star^{\star}{ }^{\star \star \star}$ Fakultas Hukum Universitas Jambi \\ ${ }^{\star \star}$ Universitas Bangka Belitung \\ ^usman.marjamat@unja.ac.id
}

\begin{abstract}
Reflecting on the impact of adultery, adultery is a despicable act that deserves to be criminalized. Even so, the prohibition on adultery in Article 284 of the Criminal Code does not cover every form of adultery as in the view of the law that lives in society as reflected in Islamic and customary laws. The model for the formulation of the criminal act of adultery in the 2019 Criminal Code Bill has adopted the definition of adultery from the law that lives in society, although it does not yet view the perpetrator's marital status and pregnancy as burdensome elements. Likewise, it does not criminalize women who with their consent commit adultery because of trickery, and lightly penalize the perpetrators of living together as a family without being married. Therefore, the model for the formulation of the criminal act of adultery in the upcoming Criminal Code Bill should take into account: a) the marital status of the perpetrator and pregnancy as elements that are burdensome for the crime; b) a woman who with her consent commits adultery because of a trick is both a victim and a perpetrator so that she can be convicted; c) persons who live together as husband and wife outside of marriage should receive a heavier punishment than the basic form of adultery.
\end{abstract}

Keywords: Islamic law; customary law; adultery; criminal law reform. 


\section{Abstrak}

Bercermin dari dampak perzinaan, maka perzinaan merupakan perbuatan tercela yang pantas dikriminalisasi. Meskipun demikian, larangan perzinaan dalam Pasal 284 KUHP belum mencakup setiap bentuk perzinaan sebagaimana dalam pandangan hukum yang hidup dalam masyarakat yang tercermin dari hukum Islam dan hukum adat. Model perumusan tindak pidana perzinaan dalam RUU KUHP tahun 2019 telah mengadopsi definisi zina dari hukum yang hidup dalam masyarakat, meskipun belum memandang status perkawinan pelaku dan kehamilan sebagai unsur yang memberatkan. RUU juga tidak mengkriminalisasi perempuan yang dengan persetujuannya melakukan perzinaan karena tipu muslihat, dan memidana ringan pelaku hidup bersama sebagai keluarga tanpa nikah. Oleh karena itu model pengaturan tindak pidana perzinaan dalam RUU KUHP mendatang sebaiknya memerhatikan: a) status perkawinan pelaku dan kehamilan sebagai unsur yang memberatkan pidana; b) perempuan yang dengan persetujuannya melakukan perzinaan karena tipu muslihat merupakan korban sekaligus pelaku sehingga dapat dipidana; c) orang yang melakukan hidup bersama sebagai suami istri di luar perkawinan seharusnya mendapat pidana lebih berat dibanding jenis perzinaan dalam bentuk pokok.

Kata kunci: hukum Islam; hukum adat; perzinaan; pembaruan hukum pidana.

\section{A. Pendahuluan}

Artikel ini berusaha menganalisis keselarasan nilai-nilai peraturan tentang perzinaan dalam Pasal 284 Kitab Undang-Undang Hukum Pidana (KUHP) dan Rancangan Undang-Undang (RUU) KUHP 2019 dengan hukum yang hidup dalam masyarakat Indonesia yang tercermin dari hukum Islam dan hukum adat. Dengan menelaah nilai-nilai positif hukum Islam dan hukum adat yang dapat diserap, diharapkan diperoleh model rumusan pasal tindak pidana perzinaan yang dapat dituangkan dalam RUU KUHP.

Perzinaan merupakan masalah sosial yang masih terus eksis di tengah-tengah masyarakat. Dalam konteks tatanan nilai norma sosial, perzinaan merupakan perilaku menyimpang yang bersifat anti sosial. Hal ini karena perzinaan menimbulkan dampak kerugian besar, baik 
yang bersifat individu pelaku, keluarga, maupun masyarakat. Bahkan dalam konteks yang lebih luas juga menimbulkan kerugian bagi bangsa. Akibat langsung dari perzinaan adalah terjadinya kehamilan yang tidak diinginkan, yang sebagian berakibat pada terjadinya aborsi ilegal. Badan Kependudukan dan Keluarga Berencana Nasional (BKKBN) memperkirakan ada sekitar dua juta kasus aborsi yang terjadi setiap tahunnya di Indonesia. Hal ini berarti ada dua juta nyawa yang sengaja dibunuh setiap tahunnya. ${ }^{1}$ Sementara hasil penelitian Perkumpulan Keluarga Berencana Indonesia (PKBI) menemukan sekitar 15 persen remaja usia 10-24 tahun, yang di Indonesia jumlahnya mencapai 62 juta, telah melakukan hubungan seksual di luar nikah, yang menyebabkan kehamilan tidak diinginkan sehingga memicu aborsi secara tidak aman. Akibatnya setiap tahun sekitar 2,3 juta kasus aborsi di Indonesia, dan dari data tersebut 20 persen di antaranya dilakukan oleh remaja. ${ }^{2}$ Jumlah ini jauh lebih besar dengan kematian karena kecelakaan di dunia yang dilaporkan oleh Global Status Report on Road Safety (WHO, 2015), yang jumlahnya mencapai 1,25 juta korban meninggal. ${ }^{3}$

Besarnya kerugian akibat perzinaan seharusnya mendorong tanggung jawab negara untuk melindungi warganya dari perzinaan. Satu bentuk tanggungjawab negara adalah melalui penguatan sosial dan kebijakan hukum pidana untuk mencegah, melarang, dan menindak pelaku perzinaan. Kebijakan hukum pidana terhadap perzinaan di Indonesia sesungguhnya telah ditetapkan dalam Pasal 284 KUHP. Permasalahannya Pasal ini hanya melarang zina yang dilakukan oleh dua orang yang telah menikah, atau salah satu dari pelaku itu sudah menikah. Peraturan tersebut tidak dapat menjerat

1 Aborsi.Org, "Statistik Aborsi”, https://www.aborsi.org/statistik.htm, diakses 6/2/2020.

2 Antaranews.com, "Penelitian PKBI Tunjukkan 15 Remaja Berhubungan Seks Pra-Nikah”, https:/ / www.antaranews.com/berita/49272/penelitianpkbi-tunjukkan-15-remaja-berhubungan-seks-pra-nikah, diakses 6/2/2020.

3 Kominfo.go.id., "Rata-rata Tiga Orang Meninggal Setiap Jam Akibat Kecelakaan Jalan”, https://kominfo.go.id/index.php/content/ detail / 10368 / rata-rata-tiga-orang-meninggal-setiap-jam-akibatkecelakaan-jalan/0/artikel_gpr, diakses 29/2/2020. 
perzinaan yang dilakukan oleh orang yang sama-sama belum mempunyai ikatan perkawinan. Menurut Hendra Surya dkk., peraturan semacam itu akhirnya dapat menimbulkan perilaku seks bebas di kalangan remaja yang belum menikah, yang berujung pada kehamilan yang tidak diinginkan dan tindakan aborsi serta penyakit kelamin dan HIV / AIDS. ${ }^{4}$

Peraturan tentang perzinaan seperti ditetapkan dalam Pasal 284 KUHP secara filosofis dan sosiologis tidak selaras dengan pemahaman tentang larangan perzinaan yang berkembang di dalam masyarakat Indonesia pada umumnya, yang dilandasi oleh nilai hukum adat dan hukum Islam. Bagi masyarakat Indonesia yang religius dan komunal, perzinaan adalah setiap hubungan seksual laki-laki dan perempuan yang tidak terikat dalam perkawinan. Dalam hukum adat di berbagai daerah di Indonesia, perzinaan dipandang sebagai melawan hukum adat dengan berbagai model sanski adatnya. ${ }^{5}$ Dalam hukum Islam, larangan perzinaan didasarkan pada Al-Quran (17:32), "Dan jangan kamu mendekati perzinaan; sesungguhnya perzinan itu adalah sesuatu perbuatan yang keji dan suatu jalan yang buruk."”

Hukum adat maupun hukum Islam tegas melarang setiap bentuk perzinaan. Namun begitu, hukum adat maupun hukum Islam tidak dapat dijadikan dasar oleh penegak hukum dalam penindakan pelaku perzinaan. Sementara itu, Pasal 284 KUHP tidak mengatur setiap bentuk perzinaan yang dikenal dalam masyarakat. Kondisi demikian menjadikan kebijakan hukum pidana seharusnya dapat menyerap

4 Hendra Surya, Rusjdi Ali Muhammad, dan Mohd. Din, "Studi Perbandingan tentang Konsep Perzinaan Menurut KUHP dengan Hukum Pidana Islam”, Jurnal Ilmu Hukum, 1, 3 (2013), hlm. 75-83.

5 Handrawan, "Sanksi Adat Delik Perzinahan (Umoapi) dalam Perspektif Hukum Pidana Adat Tolaki”, Perspektif: Kajian Masalah Hukum dan Pembangunan, 21, 3 (2016), hlm. 20; Umi Rozah dan Erlyn Indarti, "Delik Zina: Unsur Substansial dan Penyelesaiannya dalam Masyarakat Adat Madura”, Masalah-Masalah Hukum, 48, 4 (2019), hlm. 372.

6 Dalam tafsir Ibnu Katsir, dalam ayat ini, maksudnya Allah melarang hambanya berbuat perzinaan dan mendekatinya serta melakukan faktorfaktor dan aspek-aspek yang mengantarkan kepada perbuatan perzinaan. Abdullah bin Muhammad Alu Syaikh, Tafsir Ibnu Katsir, Jilid 5, terj. M. Abdul Goffar (Jakarta: Pustaka Imam Syafii, 2008), hlm. 3007. 
hukum Islam dan hukum adat menjadi sumber nilai hukum yang diakomodasi dalam pembaruan hukum pidana di Indonesia. Hukum pada dasarnya tidak terlepas dari basis sosial di mana hukum itu berlaku. Hukum itu mestinya tumbuh dan ditetapkan dari nilainilai yang diyakini kebenarannya oleh masyarakat sehinggga keharmonisan nilai-nilai hukum negara dan hukum yang hidup dalam masyarakat dapat diwujudkan. Berdasarkan konsep tersebut, maka perpaduan nilai-nilai dari norma agama, norma adat, etika sosial, dan norma hukum positif merupakan kolaborasi yang ideal untuk memperbaiki kualitas peraturan perundang-undangan di Indonesia.' Dalam kaitannya dengan pembaruan hukum pidana Indonesia (KUHP), memadukan secara selaras nilai-nilai hukum agama (Islam) dan hukum dalam pasal larangan perzinaan akan dapat melahirkan norma hukum yang baik. Menurut Barda Nawawi Arief, pembaruan hukum pidana pada hakikatnya merupakan upaya melakukan peninjauan kembali (reorientasi dan reevaluasi) nilainilai sosio-politik, sosio-filosofis, dan sosio-kultural yang melandasi dan memberi isi terhadap muatan normatif dan substantif hukum pidana yang dicita-citakan. ${ }^{8}$

Penelitian terhadap tema yang sama sebelumnya telah dilakukan oleh beberapa peneliti, antara lain Hedra Surya, Rusjdi Ali Muhammad, dan Mohd. Din ("Studi Perbandingan tentang Konsep Perzinaan Menurut KUHP dengan Hukum Pidana Islam”); Umi Rozah dan Erlyn Indarti ("Delik Zina: Unsur Substansial dan Penyelesaiannya dalam Masyarakat Adat Madura"); Ishak ("Analisis Hukum Islam tentang Perbuatan Zina dalam Pasal 284 KUHP”); Hendrawan ("Sanksi Adat Delik Perzinahan [Umoapi] dalam

7 NasarudinUmar, "KonsepHukumModern:Suatu Perspektif Keindonesiaan, Integrasi Sistem Hukum Agama dan Sistem Hukum Nasional”, Walisongo: Jurnal Penelitian Sosial Keagamaan, 22, 1 (2014), hlm. 173.

8 Barda Nawawi Arief, Tujuan dan Pedoman Pemidanaan (Semarang: Badan Penerbit Magister, 2011), hlm. 16. Karena itu menurut Hanafi Amrani (Politik Pembaruan Hukum Pidana [Yogyakarta: UII Press, 2019], hlm. 85), ada empat masalah terkait pembaruan hukum pidana dalam sistem hukum Indonesia: pembaruan asas-asas hukum pidana, pembaruan konsep tindak pidana, pembaruan konsep pertanggungjawaban, dan pembaruan konsep pidana dan pemidanaan. 
Perspektif Hukum Pidana Adat Tolaki”). Namun penelitian itu pada umumnya terbatas pada tataran dogmatika hukum yang membahas apa hukumnya mengenai zina menurut hukum adat dan KUHP. Penelitian ini membedakan dengan penelitian yang sudah ada dengan mengkaji pada tataran filsafat hukum menyangkut keselarasan nilai atau dasar filosofi pelarangan zina dan politik hukum terkait apa hukum zina yang seharusnya di masa mendatang.

Kajian dalam artikel ini dilakukan melalui penelitian doktrinal atau hukum normatif. Dalam membahasnya, artikel ini setelah ini memulainya dengan penelaahan nilai-nilai perzinaan dalam hukum Islam, hukum adat, dan KUHP. Uraian ini dimaksudkan untuk menemukan keselarasan nilai-nilai hukum terkait perzinaan dalam KUHP dengan hukum Islam dan hukum adat. Bagian berikutnya mengulas model pengaturan perzinaan dalam RUU KUHP, dan dilanjutkan dengan kajian model pengaturan yang selaras dengan hukum Islam dan hukum adat. Bagian akhir artikel menyajikan jawaban ringkas terkait urgensi penyerapan nilai hukum Islam dan hukum adat dalam pengaturan perzinaan, sekaligus tawaran konseptual tentang pengaturan yang selaras tersebut di masa mendatang.

\section{B. Keselarasan Nilai-nilai Pasal Perzinaan Pasal 284 KUHP dengan Hukum Islam dan Hukum Adat}

Secara teoretis, hukum yang baik adalah hukum yang sesuai dengan nilai-nilai hukum yang hidup dalam masyarakat. Hal ini menjadi pandangan mazhab hukum sejarah dan kebudayaan, yang dipelopori antara lain oleh Friedrich Karl von Savigny (1770-1861), dan Henry Summer Maine (1822-1888). Menurut Savigny, hukum timbul karena perasaan keadilan yang terletak dalam jiwa bangsa (volkgeist), bukan karena perintah penguasa. Hakikat sistem hukum adalah sebagai pencerminan jiwa rakyat yang mengembangkan hukum itu. Semua hukum berasal dari adat istiadat dan kepercayaan dan bukan berasal dari pembentuk undang-undang. ${ }^{9}$ Menurut Achmad Ali, dalam

9 Otje Salman Soemadiningrat, Filsafat Hukum (Perkembangan \& Dinamika) 
konteks ini maka perlu adanya keselarasaran antara law in ideas, law in the book, dan law in action. Keselarasan antara nilai-nilai ideal yang menjadi rujukan dalam pembentukan hukum yang tersirat dalam norma hukum, dengan hukum sebagai kaidah yang menentukan apa yang boleh dan apa yang dilarang untuk dilakukan, dan dengan hukum sebagai kenyataan, yang mencakup kenyataan sosial, budaya dan lainnya. ${ }^{10}$ Dalam kaitannya dengan pengaturan perzinaan, ketidakharmonisan hukum dalam Pasal 284 KUHP dengan hukum yang nyata, bukan saja persoalan aturan normatifnya belaka, melainkan juga terkait dengan nilai-nilai dasar tentang mengapa aturan itu terbentuk seperti adanya demikian.

\section{Nilai-Nilai Hukum Tindak Pidana Perzinaan Menurut Hukum Islam}

Menurut fiqh Islam, perzinaan didefinisikan sebagai persetubuhan yang dilakukan antara seorang laki-laki dan perempuan yang tidak memiliki ikatan perkawinan yang sah; persetubuhan tersebut dilakukan dengan memasukkan kelamin laki-laki ke dalam kelamin perempuan minimal sampai pada batas hasyafah (kepala zakar). ${ }^{11}$ Dalam Ensiklopedi Hukum Pidana Islam, perzinaan didefinisikan sebagai persetubuhan antara seorang laki-laki dan seorang perempuan mukallaf yang tidak terikat dalam perkawinan yang sah. ${ }^{12}$ Terdapat

(Bandung: Rafika Adhitama, 2010), hlm. 68. Lebih jauh tentang pandangan hukum dari Savigny, serta urgensi dan relevansinya saat ini, dapat dibaca pada artikel ulasan tokoh dan pemikiran hukum pada jurnal ini: M. Zulfa Aulia, "Friedrich Carl von Savigny tentang Hukum: Hukum sebagai Manifestasi Jiwa Bangsa”, Undang: Jurnal Hukum, 3, 1 (2020): 201-36.

10 Achmad Ali, Menjelajah Kajian Empiris terhadap Hukum (Jakarta: Kencana Persada Media Grup, 2012), hlm. 1-2. Dalam studi ilmu hukum pidana, konsep hukum yang mestinya bersesuaian dengan nilai-nilai Ketuhanan, sehingga disebut ilmu hukum pidana berketuhanan, diberi nama oleh Barda Nawawi Arief dengan biomijuridika (Muhammad Rustamaji, "Biomijuridika: Ilmu Hukum Pidana Berketuhanan dari Barda Nawawi Arief”, Undang: Jurnal Hukum, 2, 1 [2019]: 193-223).

11 M. Abdul Mujieb, Mabruri Tholhah, dan Syafiah AM, Kamus Istilah Fiqh (Jakarta: Pustaka Firdaus, 2002), hlm. 443.

12 Abdul Qadir Audah, Ensiklopedi Hukum Pidana Islam, terj. Salisah (Jakarta: Kharisma Ilmu, 2007), hlm. 153-154. 
perbedaan redaksi definisi perzinaan yang dikemukakan oleh para ulama mazhab, namun esensinya sama, yaitu bahwa dalam perzinaan terdapat dua unsur: a) adanya persetubuhan antara seorang laki-laki dan perempuan, dan b) laki-laki atau perempuan tersebut tidak ada ikatan perkawinan yang sah. ${ }^{13}$

Dalam hukum Islam, larangan perzinaan didasarkan pada AlQuran (17:32): "Dan jangan kamu mendekati perzinaan; sesungguhnya perzinaan itu adalah sesuatu perbuatan yang keji dan suatu jalan yang buruk." Dalam tafsir Ibnu Katsir disebutkan, ayat ini merupakan larangan Allah kepada hamba-Nya berbuat zina, mendekatinya, serta melakukan hal-hal yang mengantarkan pada perbuatan perzinaan. ${ }^{14}$ Larangan perzinaan menurut hukum Islam juga mengacu hadis Nabi Muhammad SAW, sebagaimana diriwayatkan dari Abdullah bin Mas'ûd, dikategorikan sebagai bagian dari dosa besar. Sejak dahulu hingga sekarang, kaum muslimin sepakat bahwa perbuatan perzinaan itu haran. Imam Ahmad bin Hambal berkata: "Saya tidak tahu ada dosa yang lebih besar dari perzinaan (selain) pembunuhan." 15

Pelaku perzinaan dalam hukum Islam dibedakan antara yang berstatus telah menikah (al-muhshân) dan yang belum menikah (albikr). Keduanya memiliki sanksi berbeda. Hukuman bagi pelaku perzinaan yang pernah menikah (al-muhshân) adalah rajam (dilempar dengan batu) sampai mati. Hukuman ini berdasarkan al-Qur`an, hadis mutawatir dan ijma' kaum muslimin. ${ }^{16}$ Sedangkan pelaku perzinaan yang belum memenuhi kriteria al-muhshân, maka hukumannya adalah dicambuk sebanyak seratus kali. Ini adalah kesepakatan para ulama berdasarkan firman Allah: "Perempuan yang berzina dan lakilaki yang berzina, maka deralah (cambuklah) tiap-tiap seorang dari keduanya seratus kali dera (cambuk)” (Al Quran [24:2]). ${ }^{17}$ Beratnya sanksi bagi pelaku perzinaan memerlukan kehati-hatian dalam penerapannya. Oleh karena itu dalam hukum Islam diperlukan

13 Ahmad Wardi Muslich, Hukum Pidana Islam (Jakarta: Sinar Grafika, 2005), hlm. 6-7.

14 Syaikh, Tafsir Ibnu Katsir, hlm. 307.

15 Syaikh, Tafsir Ibnu Katsir, hlm. 475.

16 Syaikh, Tafsir Ibnu Katsir, hlm. 475.

17 Syaikh, Tafsir Ibnu Katsir, hlm. 313. 
empat saksi untuk pembuktiannya, sebagaimana firman Allah, "Dan (terhadap) para wanita yang mengerjakan perbuatan keji, hendaklah ada empat orang saksi di antara kamu (yang menyaksikannya)." ${ }^{18}$

Beratnya ancaman pidana terhadap pelaku perzinaan dalam hukum Islam sebanding dengan dampak yang ditimbulkannya. Perzinaan dapat menimbulkan kerusakan jasmani seperti timbulnya penyakit kelamin, kerusakan moral, serta hilangnya sifat kemuliaan, keutamaan dan keluhuran, kerusakan struktur kehidupan masyarakat dan keluarga, mengacaukan katurunan, memutuskan hubungan suami isteri, serta merusak pendidikan anak. Selain itu, perzinaan juga membawa dampak pada timbulnya tindak pidana lain, misalnya aborsi atau pembunuhan bayi yang lahir akibat perbuatan perzinaan tersebut. ${ }^{19}$

Uraian di atas, dilihat dari sisi teori kebijakan hukum pidana, menunjukkan bahwa hukum Islam memandang perzinaan sebagai suatu perilaku yang tidak termasuk dalam private ethics, melainkan public ethics, sehingga harus dikriminalisasi dikarenakan sangat merugikan masyarakat. ${ }^{20}$ Konsekuensi dari penempatan perzinaan ke dalam public ethics, maka konsep perzinaan menurut hukum Islam mesti diartikan secara luas, bahwa perzinaan adalah setiap hubungan seksual antara laki-laki dan perempuan di luar ikatan perkawinan yang sah dan telah memenuhi persyaratan perzinaan, dengan tidak membedakan apakah pelaku telah menikah atau belum. Meskipun demikian pembuktian tindak pidana perzinaan dalam hukum Islam sangat ketat. Berbeda dengan hukum Indonesia yang cukup menghadirkan dua saksi untuk bukti perzinaan, dalam hukum Islam membutuhkan ketarangan empat orang saksi.

Berdasarkan sifat tercelanya perbuatan, hukum Islam memandang bahwa perzinaan merupakan perbuatan yang keji dan sangat

18 Kholid Syamhudi, "Hukuman Untuk Pezina”, https: / / almanhaj.or.id/2641hukuman-untuk-pezina.html, diakses 11/9/2020.

19 Ishak, "Analisis Hukum Islam tentang Perbuatan Zina dalam Pasal 284 KUHP,” Kanun Jurnal Ilmu Hukum, 14, 1 (2012), hlm. 170; Aborsi.org, "Statistik Aborsi"; Antaranews.com, "Penelitian PKBI".

20 Salman Luthan, "Asas dan Kriteria Kriminalisasi”, Jurnal Hukum Ius Quia Iustum, 16, 1 (2009), hlm. 17. 
buruk. Oleh karena itu, kepada pelakunya diancam sanksi pidana yang sangat berat berupa seratus kali dera atau pidana mati berupa rajam. Dikaitkan dengan teori pemidanaan, jenis sanksi pidana mati itu mencerminkan pembalasan. Meskipun demikian, dengan melihat cara pelaksanaannya, sesungguhnya mencerminkan pula teori tujuan, yaitu untuk melakukan pencegahan perzinaan berikutnya. Karena dengan pidana mati itu dimaksudkan agar orang lain tidak melakukan perbuatan yang sama, sehingga bersifat pencegahan umum. Sedangkan untuk sanksi pidana cambuk dan pegasingan, dalam kerangka teori pemidanaan mencerminkan teori tujuan, yaitu untuk pencegahan yang bersifat khusus berupa keinsafan pelaku dan pencegahan bagi masyarakat umum. ${ }^{21}$

\section{Nilai-nilai Hukum Tindak Pidana Perzinaan Menurut Hukum Adat}

Hukum pidana adat merupakan kebiasaan yang mengatur perbuatan salah yang berakibat dihukum agar keseimbangan masyarakat tidak terganggu. Jadi yang diatur adalah peristiwa yang merupakan delik adat termasuk cara menyelesaikannya untuk menjamin keseimbangan masyarakat. ${ }^{22}$ Perzinaan merupakan pelanggaran adat dalam setiap masyarakat adat di Indonesia meskipun dengan istilah berbeda-beda. Dalam hukum adat perzinaan merupakan suatu perbuatan yang merusak kesusilaan masyarakat. Perzinaan merupakan peristiwa yang menggoncangkan neraca keseimbangan masyarakat, mencemarkan kehormatan kerabat, mengganggu kesucian dan merusak tatanan kehidupan. Menurut Iman Sudiyat, perzinaan merupakan pelanggaran terhadap kehormatan kerabat dan melanggar kepentingan hukum suami/istri. ${ }^{23}$ Menurut R. Soepomo, perzinaan tidak saja melanggar kepentingan hukum seseorang sebagai

21 Puteri Hikmawati, "Pidana Pengawasan sebagai Pengganti Pidana Bersyarat Menuju Keadilan Restoratif”, Negara Hukum, 7, 1 (2016), hlm. 76.

22 Tolip Setiady, Intisari Hukum Adat Indonesia (Bandung: Alfabeta, 2009), hlm. 345.

23 Iman Sudiyat, Hukum Adat Sketsa Asas (Yogyakata: Liberty, 1981), hlm. 193. 
suami/istri tetapi juga melanggar kehormatan golongan famili. ${ }^{24}$ Konsep perbuatan seperti ini menjadikan perzinaan bukan semata kepentingan hukum pribadi, tetapi juga merupakan perlindungan terhadap keluarga besar atau famili.

Dengan keragaman suku bangsa dan adat istiadat di Indonesia, terdapat hukum pidana adat yang berbeda dari satu lingkungan hukum adat dengan lainnya. Namun demikian, meski istilah yang digunakan untuk merepresentasikan perzinaan berbeda-beda, tetapi nilai-nilai yang terkandung di dalamnya tampaknya kurang lebih sama. Menurut Hilman Hadikusuma, perzinaan menurut hukum adat adalah persetubuhan antara pria dan wanita di luar ikatan perkawinan yang sah. ${ }^{25}$ Pendapat ini hampir sama dengan konsep perzinaan dalam hukum pidana adat Kampar Persukuan Domo Air Tiris, yang tertuang dalam hukum cupak nan ompek, perzinaan merupakan setiap hubungan seksual atau persetubuhan yang dilakukan di luar perkawinan yang sah. Pelakunya bisa saja orang yang sudah menikah maupun sama-sama belum menikah. ${ }^{26}$ Dalam hukum adat Madura, perzinaan adalah persetubuhan antara laki-laki dan perempuan, baik yang sudah menikah, atau salah satunya sudah menikah maupun sama-sama belum menikah yang keduanya tidak terikat dalam perkawinan yang sah. ${ }^{27}$ Dalam Hukum Adat Tolaki, yang tertuang dalam Kalo Sara, memandang setiap persetubuhan di luar ikatan perkawinan adalah perzinaan, tanpa melihat status perkawinan. ${ }^{28}$

24 R. Soepomo, Bab-Bab tentang Hukum Adat (Jakarta: Pradnya Paramita, 1993), hlm. 125.

25 Hilman Hadikusumah, Hukum Pidana Adat (Bandung: Alumni, 1984), hlm. 98.

26 Muhammad Ridoi, Erdianto, dan Ledy Diana, "Penerapan Pidana Adat dan Pidana KUHP terhadap Pelaku Tindak Pidana Zina Dikaitkan dengan Peran Kepolisian (Studi Kasus di Wilayah Hukum Persukuan Domo Air Tirs dan Polres Kampar)", https://jom.unri.ac.id/index.php/JOMFHUKUM/ article/view/16571, hlm. 6-7.

27 Rozah, "Delik Zina”, hlm. 374.

28 Harisman, Sabrina Hidayat, dan Handrawan, "Penyelesaian Delik Perzinahan dalam Hukum Adat Tolaki," Halu Oleo Legal Research, 1, 1 (2019), hlm. 66. 
Beragam hukum adat di Indonesia sebagaimana paparan sebelumnya, memperlihatkan kesamaan nilai-nilai mengenai konsep perzinaan, yang intinya adalah persetubuhan antara lakilaki dan perempuan di luar ikatan perkawinan yang sah, tanpa melihat apakah pelakunya telah terikat dalam perkawinan atau belum. Konsep perzinaan seperti ini menunjukkan bahwa perzinaan bukan merupakan pelanggaran yang bersifat privat secara mutlak, melainkan juga pelanggaran yang berakibat pada keluarga dan lingkungan sosialnya. Hal ini menjadikan pengaduan dalam hukum adat untuk menindak pelanggaran hukum adat berupa perzinaan tidak mutlak berada pada suami atau istri yang dihiananti, tetapi juga berada pada keluarga besar dan masyarakat di lingkungannya. Sifat perbuatan perzinaan dalam hukum adat menunjukkan kesamaan dengan hukum Islam, demikian juga mengenai pengertian perzinaan. Hal ini menunjukkan keselarasan antara hukum adat dengan hukum Islam dalam mengatur larangan perzinaan.

Sanksi pidana adat merupakan pemenuhan kewajiban adat yang dijatuhkan oleh kepala adat terhadap orang yang telah melanggar hukum adat. ${ }^{29}$ Berat atau ringannya sanksi adat terhadap pelaku perzinaan sangat tergantung dari bentuk atau jenis perzinaan yang dilakukan. Dalam hukum adat dikenal berbagai bentuk perzinaan. Mengenai reaksi hukum adat terhadap perzinaan terdapat keragaman dalam hukum adat di nusantara. Misalnya di Kupang, pelaku diwajibkan mengawini perempuan tersebut. Apabila pelaku laki-laki tidak mau bertanggungjawab atas perbuatannya, maka sanksinya dapat berupa: (a) naek nafani nesu, matan kotenn (tutup pintu muka belakang) berupa seekor sapi yang berumur satu adik, (b) toeb tais hae manak (tutup malu, pemulihan nama baik perempuan) berupa tiga ekor sapi masing-masing berumur satu adik. ${ }^{30}$

Sanksi hukum pidana adat bagi pelaku perzinaan pada masyarakat adat Dayak, termasuk yang paling berat, yaitu apabila perbuatan perzinaan itu tertangkap tangan, maka suami dibolehkan membunuh

29 Sudiyat, Hukum Adat Sketsa Asas, hlm. 193.

30 Otje Salman Soemadiningrat, Rekonseptualisasi Hukum Adat Kontemporer (Bandung: Alumni, 2011), hlm. 17. 
isterinya dan pria pasangan perzinaannya. Suami yang membunuh itu tidak dianggap salah, jika ia melaporkan pembunuhan tersebut pada saat itu juga kepada kepala adat. ${ }^{31}$ Sedangkan pada masyarakat adat Tolaki, sanksi bagi pelaku perzinaan ditentukan berdasarkan kondisi. Apabila perempuan pelaku perzinaan tidak hamil, maka sanksinya adalah dikawinkan. Namun jika salah satu pihak menolak, maka sanksinya denda berupa: (a) satu pies kain kaci (tidak boleh diuangkan), (b) satu ekor kerbau (boleh diuangkan), dan (c) satu buah cerek air dari tembaga (tidak boleh diuangkan). Sedangkan apabila perempuan pelaku perzinaan) itu hamil, maka sanksinya adalah dikawinkan. Tetapi apabila salah satu pihak menolak, maka harus membayar denda adat, berupa: (a) satu pies kain kaci (tidak dapat diuangkan), (b) satu ekor kerbau (tidak boleh diuangkan). ${ }^{32}$

Dalam masyarakat Minang di Lubuk Basung, sanksi adat yang dapat dijatuhkan pada pelaku perzinaan adalah: pertama, dibuang dari daerah pelaku perzinaan, dengan berbagai variasinya, meliputi: buang siriah, buang tambika, buang saro, buang utang, dan buang pulus. Kedua, denda yang ditetapkan bersama berupa sejumlah uang atau emas yang disepakati oleh kaum untuk memberi makan kaum "pasukan", biasanya terdiri dari: beras satu pikul, satu ekor jawi, beserta sirih dan carano. Denda lainnya dapat berupa material untuk pembangunan fasilitas umum. Pengenaan sanksi adat perzinaan menurut hukum adat Minang diklasifikasi berdasarkan pelakunya, yaitu: a) apabila pelaku perzinaana dilakukan oleh orang sesuku, maka sanksinya pelaku dikeluarkan dari daerah yang bersangkutan; b) apabila pelaku perzinaan dilakukan oleh orang yang berbeda suku, maka sanksinya pelaku akan dikawinkan dulu kemudian dikeluarkan dari daerah yang bersangkutan; c) apabila pelaku perzinaan dilakukan oleh ninik mamak, maka sanksinya pelaku diberhentikan dari jabatannya sebagai ninik mamak, kemudian dikeluarkan dari daerah yang bersangkutan; d) apabila pelaku perzinaan dilakukan oleh empat serangkai yaitu lanai, khatib, imam dan bilal, maka sanksinya pelaku dikeluarkan dari

31 Sudiyat, Hukum Adat Sketsa Asas, hlm. 176.

32 Handrawan, "Sanksi Adat Delik Perzinaan (Umo-pi) dalam Perspektif Hukum Pidana Adat Tolaki”, Jurnal Perspektif, 21, 3 (2016), hlm. 209. 
daerah yang bersangkutan dan disisihkan dari masyarakat. ${ }^{33}$

Berdasarkan aturan beberapa hukum adat yang diuraikan, terlihat bahwa perzinaan diklasifikasikan ke dalam beberapa bentuk atau jenis. Pertama, pelakunya, dan kedua, akibatnya bagi si perempuan. Mengenai pelakunya dapat dilihat dari: pertama, dari sisi status perkawinannya dan status/jabatan sosialnya; kedua, dari sisi akibatnya (hamil/tidak hamil); ketiga, dari sisi hubungan kekerabatannya antara laki-laki dan perempuan yang berzina. Berdasarkan klasifikasi tersebut hukum adat sudah mengatur tentang setiap perbuatan yang diklasifikasikan sebagai perzinaan. Dalam hukum adat juga sudah dikenal konsep "inses" ${ }^{34}$ sebagaimana dalam hukum adat Jambi, yang dikenal dengan: a) menikam bumi (berbuat salah dengan ibunya yang haram nikah) b) mencarak telur (berbuat salah dengan anak perempuan sendiri), c) menyunting bungo setangkai (berbuat salah dengan ipar, bisan atau adik/saudara sendiri).

Sanksi adat bagi pelaku perzinaan beragam dan berjenjang mulai dari yang paling ringan, yaitu dinikahkan, sampai dengan yang paling berat hukuman mati. Jenis sanksi adat terhadap pelaku perzinaan bersifat pemulihan yang bersifat magis/kosmos. Sanksi adat berupa denda bukan untuk negara/lembaga adat, tetapi untuk masyarakat umum lingkungan adatnya. Oleh karena itu dari sisi teori pemidanaan, sanksi adat perzinaan lebih mencerminkan teori relatif atau teori tujuan. ${ }^{35}$ Sanksi ditujukan untuk mengembalikan keseimbangan lingkungan masyarakat sehingga tidak terulang perbuatan yang sama. Dikaitkan dengan sistem sanksi dalam hukum pidana Islam, sanksi adat perzinaan untuk sebagian sama dengan sanksi perzinaan dalam hukum Islam, yaitu sanksi dibuang ke luar

33 Bobi Handoko, Erdianto Effendi, dan Rahmad Hendra, "Penerapan Sanksi Pidana Adat terhadap Pelaku Zina di Wilayah Kanagerian Garagahan Kecamatan Lubuk Pasung Kabupaten Agam,” https://jom.unri.ac.id/ index.php/JOMFHUKUM/article/view/5855, hlm. 8-9.

34 Dalam studi ini, inses didefinisikan sebagai hubungan seksual yang terjadi antara kerabat dekat, biasanya antara anggota keluarga. Lihat Amanda dan Hetty Krisnani, "Analisis Kasus Anak Perempuan Korban Pemerkosaan Inses", Focus: Jurnal Pekerjaan Sosial, 2, 1 (2019), hlm. 122.

35 Hikmawati, "Pidana Pengawasan", hlm. 76. 
daerahnya.

\section{Nilai-nilai Hukum Tindak Pidana Perzinaan dalam Pasal 284 KUHP}

Rumusan tindak pidana perzinaan dalam KUHP termuat dalam Pasal 284 Buku II. Menurut Syamsul Huda, Pasal 284 ayat (1) KUHP tidak dengan jelas mendefinisikan perzinaan, tetapi cenderung menentukan kriteria pelaku yang dapat dipidana karena melakukan perzinaan. ${ }^{36}$ KUHP hanya memberikan definisi hukum tindak pidana perzinaan, yaitu hubungan seksual atau persetubuhan di luar perkawinan yang dilakukan oleh seorang laki-laki dan seorang perempuan yang keduanya atau salah satunya terikat perkawinan dan berlaku baginya asas monogami, yang dalam hal ini seorang lakilaki hanya boleh memiliki satu istri dan sebaliknya. Oleh karena itu untuk mengetahui pengertian tentang perzinaan dilakukan melalui penafsiran dan doktrin. Menurut R. Soesilo, hubungan seksual adalah perpaduan kelamin laki-laki dan perempuan yang biasa dijalankan untuk mendapatkan anak, yaitu kelamin laki-laki masuk ke dalam anggota kelamin perempuan, sehingga mengeluarkan air mani. ${ }^{37}$ Jika hubungan seksual itu dilakukan oleh orang yang bukan istri atau suaminya maka merupakan perzinaan menurut Pasal 284 KUHP.

Pasal 284 KUHP mensyaratkan salah satu atau keduanya harus sudah kawin. Sebagai konsekuensinya, maka bukan merupakan tindak pidana perzinaan ketika hubungan seksual di luar nikah itu dilakukan oleh orang yang sama-sama tidak terikat perkawinan. Konsep pengaturan perzinaan seperti ini tidak terlepas dari latar belakang masyarakat Belanda, sebagai asal dari KUHP. Karenanya menurut M. Sudrajat, hukum pidana di Indonesia dipengaruhi oleh nilai-nilai tradisi Eropa, khususnya Belanda. Bagi masyarakat Belanda, seorang laki-laki maupun perempuan yang sudah kawin, dikatakan

36 Syamsul Huda, "Zina dalam Perspektif Hukum Islam dan Kitab Undang Undang Hukum Pidana”, Hunafa: Jurnal Studia Islamika, 12, 2 (2015), hlm. 386.

37 R. Soesilo, Kitab Undang-Undang Hukum Pidana serta Komentar Komentarnya Lengkap Pasal Demi Pasal (Bogor: Polites, 1996), hlm. 209. 
melakukan tindak pidana berzina apabila bersetubuh dengan orang ketiga. ${ }^{38}$

Berkenaan dengan hal tersebut, menurut Otje Salman, KUHP Indonesia yang saat ini berlaku adalah sebuah proses imperialisasi sekularistik yang hidup melalui transplantasi dari pemikiran barat dan diterima begitu saja oleh bangsa Indonesia tanpa menyaringnya terlebih dahulu. ${ }^{39}$ Dikatakan sekularistik karena aturan tindak pidana perzinaan sebagaimana dirumuskan dalam Pasal 284 KUHP tidak memperhatikan nilai-nilai agama, tetapi semata mengacu pada nilai-nilai masyarakat Belanda yang individualis dan sekuler, yang memandang perkawinan sebagai sebagai perjanjian atau kontrak kesetiaan sebagai suami istri, sehingga ketika salah satu pihak berzina dipandang melanggar kontrak atau melakukan penghianatan terhadap kesetiaan dalam perkawinan yang merugikan salah satu pihak.

Pada konteks masyarakat Indonesia, rumusan tindak pidana perzinaan yang dirumuskan dalam Pasal 284 KUHP jelas tidak sesuai dan bertentangan dengan nilai-nilai hukum yang hidup dalam masyarakat yang tercermin dalam hukum adat dan hukum Islam. Dalam hukum adat maupun hukum Islam, larangan perzinaan berlaku bagi setiap hubungan seksual antara laki-laki dan perempuan di luar ikatan perkawinan yang sah, tanpa kecuali bagi yang belum menikah. Dengan rumusan Pasal 284 yang berlaku di Indonesia, dikaitkan dengan fakta sosiologis dan filosofis tentang idea hukum perzinaan di Indonesia, ada kekosongan kaidah hukum tentang perzinaan, yaitu aturan yang melarang perzinaan bagi yang belum terikat perkawinan, sehingga dilihat dari sisi teori keberlakuan hukum ada permasalahan filosofis dan sosiologis.

Berdasarkan Pasal 284 ayat (2), tindak pidana perzinaan merupakan jenis tindak pidana aduan, yaitu tindak pidana yang dilakukan penuntutan atas dasar pengaduan pihak korban atau pihak yang merasa dirugikan. Jadi pasal ini memberikan hak penuh

38 M. Sudrajat Bassar, Tindak-Tindak Pidana Tertentu di dalam Kitab UndangUndang Hukum Pidana (Bandung: Remaja Rosdakarya, 1986), hlm. 166.

39 Salman, Rekonseptualisasi Hukum Adat, hlm. 79. 
kepada suami atau istri yang tercemar atau menjadi korban dari tindak pidana perzinaan yang terjadi untuk mengadukan atau tidak mengadukan. Delik aduan dalam Pasal 284 merupakan delik aduan absolut, sehingga tidak dapat dituntut satu pihak saja di antara pelakunya. Ketika suami atau istri yang menjadi korban tindak pidana perzinaan, maka tidak dapat melakukan pengaduan hanya kepada salah seorang saja, misalnya penyerta saja sedangkan istrinya tidak diadukan..$^{40}$ Menurut Adami, karena sifat tindak pidana perzinaan harus diwujudkan oleh dua orang, maka disebut dengan penyertaan mutlak, yang keduanya tidak dapat dipisahkan satu dengan yang lain. ${ }^{41}$ Pasal 284 KUHP memperlihatkan bahwa perzinaan dianggap sebagai ranah private ethics, bukan public ethics. ${ }^{42}$ Akibatnya, perzinaan adalah urusan pribadi masing-masing pelakunya. Bagi pelaku yang sudah menikah, baru dianggap merugikan pasangannya, sehingga perkara tindak pidana perzinaan menjadi hak penuh korbannya untuk mengadu atau tidak mengadu.

Berdasarkan Pasal 284 ayat (2), batas waktu pengaduan adalah tiga bulan diikuti dengan permintaan bercerai atau pisah meja dan ranjang karena alasan itu juga. Jadi pengaduan harus disampaikan dalam waktu tiga bulan dan pada masa itu juga dikuti dengan pengajuan perceraian. Namun ketentuan waktu ini tidak berlaku dan pengaduan dapat ditarik kembali selama pemeriksaan dalam sidang pengadilan belum dimulai.

Tidak seperti hukum Islam dan hukum adat yang membuat klasifikasi jenis perzinaan, Pasal 284 KUHP membedakan antara tindak pidana perzinaan dan tindak pidana turut serta perzinaan. Meskipun demikian, KUHP tidak membedakan berat pidananya. KUHP menentukan ancaman pidana bagi pelaku perzinaan adalah pidana penjara paling lama sembilan bulan. Pidana ini sangat ringan, atau dikategorikan sebagai pidana penjara jangka pendek,

40 Eddy O.S. Hiariej, Prinsip-Prinsip Hukum Pidana (Yogyakarta: Cahaya Atma Pustaka, 2016), hlm. 145.

41 Adami Chazawi, Tindak Pidana mengenai Kesopanan (Jakarta: Raja Grafindo Persada, 2005), hlm. 61.

42 Luthan, "Asas dan Kriteria Kriminalisasi”, hlm. 10. 
karena kurang dari satu tahun. Padahal jika dilihat dari dampak perbuatannya, seharusnya dipidana lebih berat.

Sebagai perbandingan, di Malaysia, bagi pelaku perzinaan berdasarkan Akta A612 dapat dipidana tiga tahun penjara dan denda RM 5000.00 (Rp 18.285.000,00) dan 61 sebatan cambuk yang dapat dijatuhkan secara kumulatif. ${ }^{43}$ Demikian juga jika dibandingkan dengan sanksi pelaku perzinaan dalam hukum Islam dan hukum adat yang memberikan sanksi relatif berat bagi pelakunya. Oleh karena itu, dalam praktik sering ditemui perkara tindak pidana perzinaan di berbagai daerah dan lingkungan hukum adat tidak diselesaikan melalui peradilan, tetapi melalui mekanisme hukum adat. Hal ini dikarena kan pidana dalam Pasal 284 KUHP tidak sesuai dengan rasa keadilan dan hukum adat yang berlaku dalam masyarakat.

Digunakannya pidana penjara sebagai ancaman pidana bagi pelaku perzinaan dalam Pasal 284 KUHP menunjukkan dasar pidana tersebut adalah teori relatif/tujuan. ${ }^{44}$ Dengan jenis pidana itu, maka pada ujungnya adalah menjalani pidana di lembaga pemasyarakatan. Sementara berdasarkan Undang-Undang Nomor 12 Tahun 1995, pemasyarakatan bertujuan agar tidak mengulangi tindak pidana dan dapat diterima kembali oleh lingkungan masyarakat. Sanksi pidana penjara tersebut kurang selaras dengan nilai hukum yang hidup dalam masyarakat, karena dianggap belum menyelesaikan permasalahan hukum yang terjadi.

\section{Keselarasan Nilai-Nilai Hukum Pasal 284 KUHP dengan Hukum Islam dan Hukum Adat}

Kaidah hukum dalam konteks filsafat bukan sekadar teks-teks hukum yang berisi batasan tingkah laku, tetapi harus dilihat sebagai pencerminan dari asas-asas hukum dan lebih dalam adalah nilainilai hukum yang mendasari hukum. Garner mengartikan nilai secara harfiah sebagai 'makna atau arti'; 'sifat yang diinginkan'; atau 'memiliki faedah' untuk sesuatu (significance, desirability, atau

43 Syazman Bin Othman Ahmad, "Hukuman Bagi Pezina di Sarawak Malaysia”, al-Jinâyah: Jurnal Hukum Pidana Islam, 1, 1 (2015), hlm. 117. 44 Hikmawati, "Pidana Pengawasan", hlm. 76. 
utility of something). ${ }^{45}$ Sementara Henry Campbell mengartikan nilai sebagai the utility of an object in satisfying, directly or indirectly, the needs or desires of human beings...). Jadi nilai adalah faedah atas suatu tujuan atau maksud yang diharapkan dapat memuaskan, baik secara langsung maupun tidak langsung, merupakan kebutuhan atau keinginan manusia. ${ }^{46}$

Nilai merupakan suatu yang ingin dicapai, dijunjung tinggi, dan dipertahankan bersama oleh masyarakat. Nilai terkandung dalam hubungan susila, spiritual, religius, estetik, antar manusia di dalam kelompok, organisasi, dan masyarakat. Untuk mengejar nilai-nilai, lahirlah norma-norma; sebagian dari norma-norma tersebut menjadi hukum. ${ }^{47}$ Menurut Arief Sidharta, tiap kaidah hukum dijiwai oleh suatu nilai. Suatu tata hukum mencerminkan sistem nilai. Sistem nilai dikategorikan menjadi dua hal: nilai dasar, yaitu landasan atau acuan untuk mencapai sesuatu; dan nilai tujuan, yaitu sesuatu yang harus diperjuangkan untuk diwujudkan. ${ }^{48}$ Jalinan antara nilai, asas dan norma dapat dilihat dalam Gambar 1.

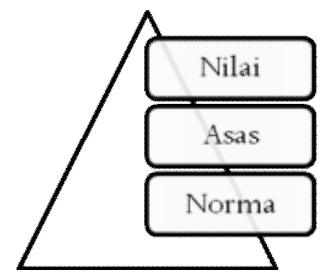

Gambar 1. Hubungan nilai, asas dan norma

Berdasarkan uraian di atas, secara anatomi, ada hubungan yang saling melengkapi antara nilai, asas dan norma. Nilai hukum

45 Bryan A. Garner, Black's La W Dictionary (Saint Paul: West Publishing Co., 2004), hlm. 4813.

46 Henry Campbell Black, Joseph R. Nollan, dan M.J. Connolly, Black'S Law Dictionary (Saint Paul: West Publishing Co., 1979), hlm. 139.

47 S. Prajudi Atmosudirjo, Hukum Administrasi Negara (Jakarta: Ghalia Indonesia, 1994), hlm. 7.

48 Bernard Arief Sidharta, Refleksi tentang Struktur Ilmu Hukum: Sebuah Penelitian tentang Fundasi Kefilsafatan dan Sifat Keilmuan Hukum sebagai Landasan Pengembangan Ilmu Hukum Nasional Indonesia (Bandung: Mandar Maju, 1999), hlm. 184. 
tidak muncul dengan sendirinya tetapi sebagai hasil dari interaksi masyarakat yang terpola mengenai sesuatu yang baik atau buruk. Selain itu, nilai juga hadir berdasarkan ajaran agama yang dianut suatu masyarakat. Demikian halnya juga dengan nilai-nilai terkait dengan aturan yang melarang perzinaan.

Aturan dalam Pasal 284 KUHP memiliki nilai-nilai yang berbeda dengan aturan yang ada dalam hukum adat dan hukum Islam. Dalam Pasal 284 KUHP larangan perzinaan itu berlaku ketika pelaku sudah menikah atau salah satunya sudah menikah. Aturan semacam ini tidak didasarkan pada tercelanya perzinaan, tetapi memandang perselingkuhannya itulah yang tercela. Jadi lebih menekankan pada nilai-nilai kesetiaan pasangan suami istri. Perzinaan dipandang sebagai perbuatan yang masuk dalam wilayah privat ethics, sehingga pasal ini berusaha memberikan perlindungan hukum terhadap korban perzinaan bukan pada sifat tercelanya perbuatan zina. Hal ini dapat dilihat pada Gambar 2.

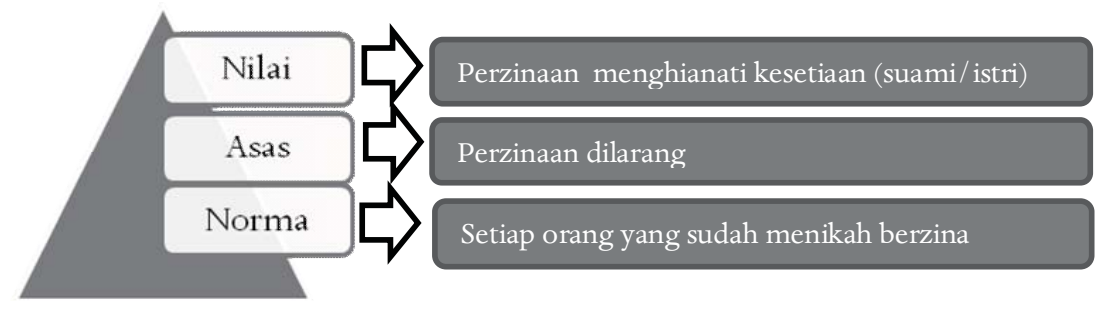

Gambar 2. Hubungan Nilai, Asas dan Norma Pasal 284 KUHP

Hukum Islam dan hukum adat relatif memiliki kesamaan nilai terhadap larangan perzinaan, namun berbeda dalam hal bobot tercelanya perzinaan. Dalam hukum Islam, perzinaan merupakan perbuatan keji dan jalan yang sangat buruk, sehingga dikategorikan sebagai dosa besar (kesalahan yang berat). Berbeda dengan Pasal 284 KUHP, dalam hukum Islam perzinaan merupakan perbuatan yang masuk dalam wilayah public ethics sehingga menjadi hak negara untuk menuntutnya. Meskipun demikian syarat persaksian jenis tindak pidana ini juga sangat ketat, yaitu harus mendapat kesaksian minimal 
saksi orang. ${ }^{49}$ Jika tidak maka tindak pidana perzinaan itu tidak dapat diproses lebih lanjut. Hal ini sebenarnya dapat ditafsirkan bahwa dalam hukum Islam juga sangat melindungi kepentingan pelaku dari kesewang-wenangan orang yang melaporkan atau menuntut. Secara skematis, hal ini dapat dilihat pada Gambar 3.

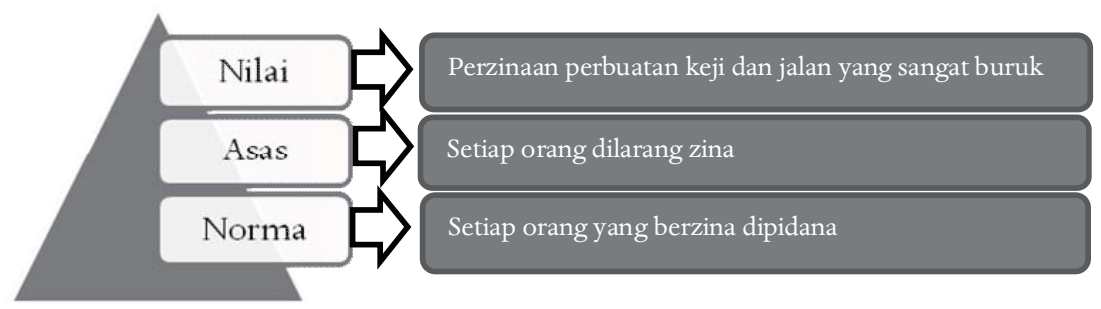

Gambar 3. Hubungan Nilai, Asas dan Norma dalam Hukum Islam

Dalam hukum adat, kategori perzinaan cukup beragam tergantung dari wilayah hukum adat masing-masing. Mulai dari yang ringan sampai yang berat. Namun pada umumnya perzinaan dipandang sebagai perbuatan sumbang yang merusak keseimbangan sosial dan lingkungan masyarakat adat, mengabaikan kesakralan perkawinan dan keturunan sah. Oleh karena itu pidana dalam hukum adat bukan sekadar derita, tetapi juga bersifat pemulihan. Hal ini dapat dilihat dalam Gambar 4.

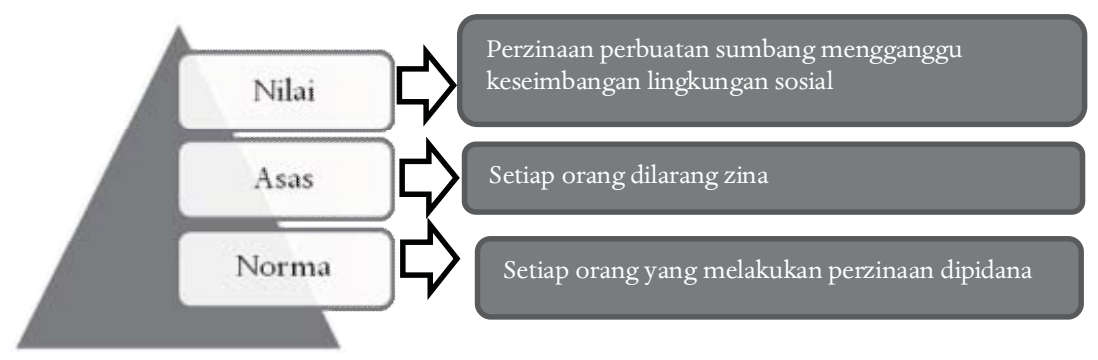

Gambar 4. Hubungan nilai, asas dan norma dalam hukum Adat

49 Zaenudin Mansyur, "Pembaruan Hukum Islam tentang Empat Saksi Lakilaki Non-Muslim dalam Kasus Li'an”, Al-Manahij: Jurnal Kajian Hukum Islam, 13, 2 (2019), hlm 286. 
Berdasarkan penjabaran sebelumnya tentang nilai, asas dan norma larangan, maka terlihat perbandingan antara Pasal 284 KUHP, hukum Islam, dan hukum adat terkait dengan perzinaan. Secara skematis, perbandingan ini ditampilkan dalam Tabel 1.

Tabel 1. Perbandingan Nilai-Nilai Hukum Larangan Perzinaan dalam Pasal 284 KUHP, Hukum Islam dan Hukum Adat

\begin{tabular}{|c|c|c|c|}
\hline Kriteria & Hukum Adat & Hukum Islam & Pasal 284 KUHP \\
\hline $\begin{array}{l}\text { Nilai } \\
\text { perbuatan }\end{array}$ & $\begin{array}{l}\text { Perbuatan yang } \\
\text { sumbang, merusak } \\
\text { kesimbangan sosial } \\
\text { dan lingkungan, } \\
\text { mengabaikan } \\
\text { kesakralan } \\
\text { perkawinan dan } \\
\text { keturunan sah }\end{array}$ & $\begin{array}{l}\text { Perbuatan yang keji } \\
\text { dan jalan yang buruk }\end{array}$ & $\begin{array}{l}\text { Perbuatan yang } \\
\text { menghianati } \\
\text { kesetiaan ikatan } \\
\text { perkawinan }\end{array}$ \\
\hline Korban & $\begin{array}{l}\text { Keluarga dan } \\
\text { masyarakat adat }\end{array}$ & $\begin{array}{l}\text { Keluarga dan } \\
\text { masyarakat umum }\end{array}$ & Suami atau istri \\
\hline Ranah & Public ethics & Public ethics & Privat ethics \\
\hline Konsep & $\begin{array}{l}\text { Setiap hubungan } \\
\text { seksual di luar } \\
\text { pernikahan/tidak sah }\end{array}$ & $\begin{array}{l}\text { Setiap hubungan } \\
\text { seksual di luar } \\
\text { pernikahan/tidak sah }\end{array}$ & $\begin{array}{l}\text { Tidak } \\
\text { memberikan } \\
\text { pengertian zina }\end{array}$ \\
\hline Jenis & $\begin{array}{l}\text { Bervariasi tergantung } \\
\text { pelakunya }\end{array}$ & $\begin{array}{l}\text { Bervariasi tergantung } \\
\text { pelakunya }\end{array}$ & $\begin{array}{l}\text { Pelaku dan } \\
\text { peserta }\end{array}$ \\
\hline $\begin{array}{l}\text { Subjek } \\
\text { yang } \\
\text { dilarang }\end{array}$ & $\begin{array}{l}\text { Setiap orang yang } \\
\text { melakukan perzinaan }\end{array}$ & $\begin{array}{l}\text { Setiap orang yang } \\
\text { melakukan perzinaan }\end{array}$ & $\begin{array}{l}\text { Zina yang } \\
\text { dilakukan oleh } \\
\text { orang yang } \\
\text { sudah menikah/ } \\
\text { salah satunya } \\
\text { sudah menikah }\end{array}$ \\
\hline $\begin{array}{l}\text { Kategori } \\
\text { Tindak } \\
\text { Pidana } \\
\end{array}$ & Delik Biasa & Delik Biasa & Delik Aduan \\
\hline
\end{tabular}

Berdasarkan Tabel 1 terlihat bahwa nilai-nilai pengaturan tindak pidana perzinaan dalam Pasal 284 KUHP tidak selaras dengan nilai hukum yang hidup dalam masyarakat yang terumuskan dalam hukum Islam dan adat. Namun demikian, dalam politik hukum pidana di Indonesia, yang berlaku adalah Pasal 284 KUHP, sehingga terjadi ketimpangan nilai mengenai hukum perzinaan di dalam masyarakat. 
Oleh karena itu dalam politik pembaruan hukum pidana ke depan, ketimpangan nilai ini harus diakhiri.

\section{Model Pengaturan Tindak Pidana Perzinaan dalam Pembaruan Hukum Pidana Indonesia}

\section{Model Pengaturan Tindak Pidana Perzinaan dalam RUU KUHP 2019}

RUU KUHP 2019 membuat klasifikasi tindak pidana perzinaan menjadi empat jenis, yaitu: tindak pidana perzinaan dalam bentuk pokok; tindak pidana perzinaan yang disetujui perempuannya karena janji akan dinikahi yang diingkari; tindak pidana perzinaan oleh pasangan keluarga di luar nikah; dan tindak pidana perzinaan antara orang yang memiliki hubungan darah. Perzinaan secara umum diatur dalam Pasal 417 ayat (1); perzinaan akibat janji untuk dinikahi yang diingkari diatur dalam Pasal Pasal 418; perzinaan dalam hidup bersama sebagai suami istri di luar perkawinan diatur dalam Pasal 419; dan perzinaan dengan anggota keluarga sedarah diatur dalam Pasal 420. Adanya klasifikasi tindak pidana perzinaan merupakan hal yang beda dengan aturan dalam Pasal 284 KUHP yang hanya mengatur dua jenis tindak pidana perzinaan, yaitu perzinaan dan turut serta melakukan perzinaan.

Dalam RUU KUHP 2019, Pasal 417, penngertian zina dirumuskan sebagai "Setiap orang yang melakukan persetubuhan dengan orang yang bukan suami atau istrinya." Batasan perzinaan ini berlaku secara umum, yang berarti apapun bentuknya juga memenuhi unsur: setiap orang; yang melakukan persetubuhan; dan dengan orang yang bukan suami atau istrinya. Selain yang ditentukan secara umum dalam Pasal 417, terdapat bentuk khusus perzinaan dalam RUU KUHP, yaitu: perzinaan yang disetujui oleh perempuannya karena janji akan dinikahi yang diingkari (Pasal 418); perzinaan oleh pasangan keluarga di luar nikah (Pasal 419); dan perzinaan antara orang yang memiliki hubungan darah (Pasal 420). Semua bentuk itu dikategorikan perzinaan karena memenuhi unsur perzinaan dalam 
Pasal 417. Jika dibandingkan dengan aturan tindak pidana dalam Pasal 284 KUHP, maka didapatkan perbedaan sebagaimana terlihat pada Tabel 2.

Tabel 2. Perbandingan Pengaturan Perzinaan dalam Pasal 284 KUHP dengan Pasal 417-419 RUU KUHP 2019

\begin{tabular}{|c|c|c|}
\hline Kriteria & KUHP & RUU KUHP 2019 \\
\hline $\begin{array}{l}\text { Definisi } \\
\text { Perzinaan }\end{array}$ & Tidak dirumuskan & $\begin{array}{l}\text { Dirumuskan, yaitu "Persetubuhan } \\
\text { dengan orang yang bukan suami } \\
\text { atau istrinya" }\end{array}$ \\
\hline $\begin{array}{l}\text { Perbuatan } \\
\text { yang dilarang }\end{array}$ & $\begin{array}{l}\text { 1. Seorang pria/ } \\
\text { wanita yang } \\
\text { telah kawin } \\
\text { yang melakukan } \\
\text { perzinaan } \\
\text { 2. Seorang pria/ } \\
\text { wanita yang turut } \\
\text { serta melakukan } \\
\text { perzinaan yang } \\
\text { pasangannya telah } \\
\text { kawin }\end{array}$ & $\begin{array}{l}\text { 1. Persetubuhan dengan orang } \\
\text { yang bukan suami atau istrinya } \\
\text { 2. Persetubuhan karena janji } \\
\text { akan dikahi yang diingkari } \\
\text { 3. Melakukan hidup bersama } \\
\text { sebagai suami istri di luar } \\
\text { perkawinan } \\
\text { 4. Persetubuhan di antara yang } \\
\text { masih memiliki hubungan } \\
\text { keluarga/ tidak boleh menikah } \\
\text { (inses) }\end{array}$ \\
\hline $\begin{array}{l}\text { Ancaman } \\
\text { Pidana }\end{array}$ & Penjara 9 bulan & $\begin{array}{l}\text { 1. Penjara } 1 \text { tahun-12 Tahun } \\
\text { 2. Denda Rp. } 10.000 .000,00- \\
\text { 200.000.000,00 }\end{array}$ \\
\hline Sifat Delik & Aduan Absolut & Aduan Absolut \\
\hline Pelaku & Suami/istri & Setiap orang \\
\hline Korban & Suami/istri & Suami/Istri, orang tua, anak \\
\hline $\begin{array}{l}\text { Yang berhak } \\
\text { mengadukan }\end{array}$ & $\begin{array}{l}\text { Suami/istri sebagai } \\
\text { korban }\end{array}$ & $\begin{array}{l}\text { Suami/Istri, orang tua, anak sebagai } \\
\text { korban }\end{array}$ \\
\hline
\end{tabular}

Berdasarkan Tabel 2 diketahui perbedaan mendasar rumusan tindak pidana perzinaan dalam Pasal 284 KUHP yang berlaku sekarang dengan rumusan tindak pidana dalam RUU KUHP 2019. Pertama, mengenai definisi hukum perzinaan, Pasal 284 KUHP tidak memberikan definisi perzinaan, melainkan hanya mengatur larangan perzinaan bagi yang sudah menikah atau salah satunya sudah menikah. Sedangkan dalam RUU KUHP 2019, diberikan batasan yang tegas, bahwa perzinaan adalah setiap orang yang melakukan persetubuhan dengan orang yang bukan suami atau istrinya. Kedua, mengenai perbuatan yang dilarang, KUHP hanya melarang perzinaan 
yang dilakukan seorang pria/wanita yang telah kawin dan seorang pria/wanita yang turut serta melakukan perzinaan yang pasangannya telah kawin. Dalam RUU KUHP, perbuatan yang dilarang lebih luas, meliputi: setiap orang yang melakukan persetubuhan dengan orang yang bukan suami atau istrinya; persetubuhan karena janji akan dinikahi yang diingkari; persetubuhan karena janji akan dinikahi yang diingkari yang berakibat kehamilan; melakukan hidup bersama sebagai suami istri di luar perkawinan; dan persetubuhan di antara yang masih memiliki hubungan keluarga/tidak boleh menikah (inses). Ketiga, mengenai ancaman pidana, dalam KUHP relatif lebih rendah. Di samping itu, KUHP menggunakan sistem ancaman tunggal berupa pidana penjara. Sedangkan dalam RUU KUHP 2019, ancaman pidana lebih berat dan dirumuskan secara alternatif antara pidana penjara dengan pidana denda.

Meskipun pengaturan tindak pidana perzinaan dalam RUU KUHP 2019 sudah mengalami kemajuan, masih ditemui beberapa titik kelemahan ketika dikaitkan dengan hukum yang hidup dalam masyarakat yang tercermin dalam hukum Islam dan hukum adat. Pertama, mengenai pelaku perzinaan, RUU KUHP 2019 tidak membedakan pelaku perzinaan yang sudah menikah dengan pelaku yang belum menikah. Dalam hukum Islam maupun hukum adat jelas membedakannya, karena memiliki akibat dan korban yang berbeda. Ditinjau dari sisi sifat tercelanya perbuatan maupun korbannya juga berbeda, yaitu pelaku yang terikat perkawinan memiliki bobot tercela yang lebih dan korban yang lebih luas dibanding dengan yang belum terikat perkawinan.

Kedua, mengenai akibat dari perzinaan, RUU KUHP tidak membedakan perzinaan yang mengakibatkan kehamilan dan yang tidak menyebabkan kehamilan. Padahal dalam kasus perzinaan yang mengakibatkan kehamilan memiliki dampak lebih luas, yang dalam banyak kasus bahkan berakibat pada aborsi ilegal. Oleh karena itu seharusnya akibat kehamilan menjadi faktor yang diperhitungkan dalam penentuan pidana bagi pelaku. Ketiga, dalam RUU KUHP 2019, terhadap perempuan yang setuju melakukan perzinaan karena ditipu sebagai korban yang tidak dipidana. Meskipun statusnya 
menjadi korban, namun ada juga peran perempuan tersebut, karena ia mengetahui bahwa perzinaan adalah melawan hukum. Keempat, pidana yang ringan terhadap pelaku hidup bersama sebagai keluarga di luar nikah. Padahal orang hidup bersama sebagai keluarga di luar nikah berarti melakukan perzinaan secara berlanjut, yang seharusnya menjadi faktor yang memberatkan pidana.

\section{Model Pengaturan Tindak Pidana Perzinaan yang Selaras dengan Nilai-Nilai Hukum Islam dan Hukum Adat}

Rumusan pasal tentang larangan perzinaan yang baik adalah rumusan yang sejauh mungkin mengadopsi hukum yang hidup dalam masyarakat, yang dalam konteks Indonesia adalah hukum Islam dan hukum adat, di samping tentu saja harus memperhatikan nilai-nilai hukum yang universal. Berdasarkan argumentasi ini, maka rumusan pasal tentang larangan perzinaan harus didasarkan pada tiga prinsip. Pertama, perzinaan merupakan perbuatan dalam lingkup privat ethics namun memiliki dampak ke dalam public ethics, sehingga dapat dikriminalisasi. Kedua, dalam kriminalisasi perzinaan, harus diberikan definisi hukum yang jelas tentang perbuatan yang dikategorikan sebagai perzinaan. Ketiga, perzinaan harus diklasifikasikan berdasarkan empat hal: motif perzinaan; kedudukan pelaku; akibat; dan status perkawinan. Beratnya ancaman pidana bagi pelaku perzinaan didasarkan pada klasifikasi perzinaan.

Mengenai definisi perzinaan, dapat disepakati rumusan dalam RUU KUHP 2019, yaitu "Persetubuhan dengan orang yang bukan suami atau istrinya". Dengan definisi ini maka mencakup setiap perzinaan yang terjadi, baik yang dilakukan oleh orang yang sudah maupun belum kawin. Definisi perzinaan seperti ini telah mencerminkan definisi perzinaan menurut hukum Islam maupun hukum adat, sehingga sudah dapat dikatakan definisi ini selaras dengan nilai hukum yang hidup dalam masyarakat.

Mengenai kualifikasi perzinaan, rumusan dalam RUU KUHP 2019 masih perlu ditambah dengan unsur: kedudukan pelaku; akibat perzinaan; dan status perkawinan pelaku. Berdasarkan kerangka 
pikir ini maka dapat dirumuskan konsep terkait dengan perzinaan sebagai berikut:

a. Perzinaan yang dilakukan oleh orang yang terikat perkawinan mempunyai bobot lebih tercela, oleh karena itu harus lebih berat ancaman pidananya.

b. Perzinaan yang menimbulkan kehamilan memiliki dampak yang lebih luas, oleh karena itu harus lebih berat ancaman pidananya.

c. Perempuan yang menyetujui berzina karena janji akan dinikahi yang diingkari bukan semata-mata korban, tetapi korban sekaligus pelaku yang dapat dipidana.

d. Perzinaan oleh pasangan keluarga di luar nikah harus lebih berat karena merupakan perzinaan yang berlanjut.

Dengan mengacu pada sistematika RUU KUHP 2019, maka pengaturan dalam mengadopsi hukum yang hidup, yaitu hukum Islam dan hukum adat dapat dirumuskan dalam dua bentuk atau model: pemberatan pidana dan perumusan ulang. Pemberatan pidana dapat diupayakan dengan menambahkan satu ketentuan yang berisi pemberatan pidana pada pasal-pasal perzinaan. Sedangkan perumusan ulang dapat diupayakan dengan menetapkan pidana pada perempuan yang dengan persetujuannya berzina, dan merumuskan yang lebih berat untuk perbuatan pasangan keluarga di luar nikah.

Model pertama, pemberatan pidana dengan cara penambahan satu ketentuan pasal. Dalam artikel ini, pasal dimaksud ialah Pasal 220A.

\section{Pasal 220A}

(1) Dalam hal perzinaan sebagaimana dimaksud dalam Pasal 217, Pasal 219, dan Pasal 220 mengakibatkan kehamilan maka pidananya ditambah sepertiga (13/) dari ancaman.

(2) Dalam hal perzinaan sebagaimana dimaksud dalam Pasal 217, Pasal 218, Pasal 219, dan Pasal 220 dilakukan oleh orang yang sudah kawin ancaman pidananya ditambah setengah dari ancaman pokok (12/).

(3) Selain pidana pokok sebagaimana dimaksud pada ayat (1) dan ayat (2) dapat dijatuhkan pidana tambahan pemenuhan kewajiban adat setempat. 


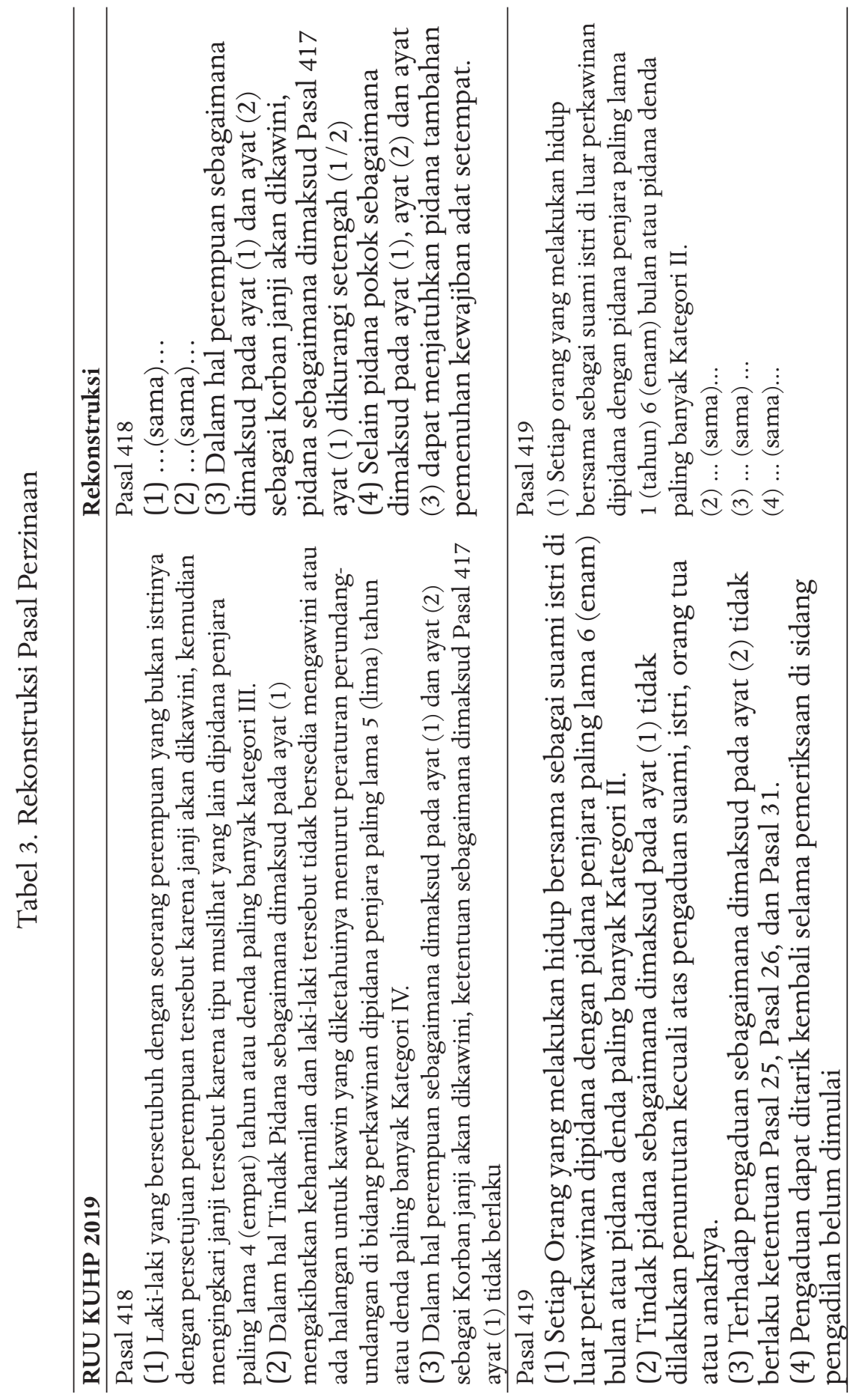


Model kedua, rekonstruksi atau perumusan ulang. Model ini dilakukan dengan merekonstruksi bangunan pasal yang mengatur tentang tindak pidana perzinaan sebagaimana yang telah dirumuskan dalam RUU KUHP. Dalam kaitannya dengan analisis sebelumnya, maka model rekonstruksi yang ditawarkan ialah sebagaimana terlihat dalam Tabel 3.

Berdasarkan Tabel 3 terlihat beberapa perbedaan model dalam RUU KUHP 2019 dengan model yang diselaraskan dengan hukum Islam dan hukum adat. Pertama, RUU KUHP 2019 tidak membedakan antara pelaku perzinaan yang sudah menikah dengan dengan yang belum menikah. Dalam model ini dibedakan, status pelaku yang sudah kawin sebagai unsur kondisi yang memberatkan pidana. Kedua, RUU KUHP 2019 tidak membedakan antara perzinaan yang mengakibatkan kehamilan dengan yang tidak menyebabkan kehamilan. Dalam model ini dibedakan sebagai unsur kondisi yang meberatkan pidana atau dasar dijatuhkannya tindakan. Ketiga, dalam RUU KUHP 2019, perempuan yang melakukan perzinaan karena ditipu (janji akan dikawini) tidak dipidana. Dalam model ini perempuan tersebut tetap dipidana dengan pidana yang ringan. Keempat, sanksi pidana untuk orang yang melakukan hidup bersama sebagai suami istri di luar perkawinan dalam RUU KUHP 2019 sangat ringan, dalam model ini diperberat karena merupakan perbuatan berlanjut.

\section{Kesimpulan}

Dalam perspektif hukum nasional ditemui ketidakselarasan nilainilai peraturan tentang perzinaan dalam Pasal 284 KUHP dengan nilai-nilai hukum yang hidup dalam masyarakat yang tercermin dari hukum Islam dan hukum adat. Hal ini dikarenakan Pasal 284 KUHP hanya melarang perzinaan bagi setiap orang yang keduanya atau salah satunya terikat perkawinan. Sedangkan dalam masyarakat adat di beberapa daerah di Indonesia, demikian juga menurut hukum Islam, larangan perzinaan berlaku untuk setiap orang. Akibatnya terdapat kekosongan hukum pidana di Indonesia untuk perzinaan 
yang dilakukan oleh orang yang belum terikat perkawinan dengan berbagai bentuknya.

Meski hukum yang hidup dalam masyarakat sudah diserap dalam ketentuan RUU KUHP 2019 terkait tindak pidana perzinaan, ia belum optimal dalam menyerap hukum yang hidup dalam masyarakat. Hal ini karena rumusannya belum mamasukkan status perkawinan pelaku dan akibat dari perzinaan yang kemungkinan menimbulkan kehamilan sebagai unsur. Rumusan RUU juga belum mengkriminalisasi perempuan yang dengan persetujuannya melakukan perzinaan karena tipu muslihat, dan memberikan ancaman ringan bagi pelaku hidup bersama sebagai keluarga tanpa nikah yang seharusnya diancam lebih berat dari bentuk perzinaan pokok. Artikel ini mendorong agar model perumusan tindak pidana perzinaan memerhatikan tiga hal berikut. Pertama, status perkawinan pelaku dan kehamilan akibat perzinaan merupakan unsur kondisi yang memberatkan ancaman pidana. Kedua, perempuan yang dengan persetujuannya melakukan perzinaan karena tipu muslihat tetap melawan hukum oleh karena itu dapat dipidana. Ketiga, orang yang melakukan hidup bersama sebagai suami istri di luar perkawinan harus lebih berat ancaman pidananya dari perzinaan pada umumnya karena ada unsur pebuatan berlanjut.

\section{Daftar Pustaka}

Aborsi.org. "Statistik Aborsi". https://www.aborsi.org/statistik. htm. Diakses 6/2/2020.

Ahmad, Syazman Bin Othman. "Hukuman Bagi Pezina di Sarawak Malaysia." Al-Jinâyah: Jurnal Hukum Pidana Islam, 1, 1 (2015): 108-24. DOI: 10.15642/aj.2015.1.1.116-128.

Ali, Achmad. Menjelajah Kajian Empiris terhadap Hukum. Jakarta:

Kencana Persada Media Grup, 2012.

Amanda dan Hetty Krisnani. "Analisis Kasus Anak Perempuan

Korban Pemerkosaan Inses." Focus: Jurnal Pekerjaan Sosial, 2, 1 (2019): 120-36. DOI: 10.24198/focus.v2i1.23129.

Amrani, Hanafi. Politik Pembaruan Hukum Pidana. Yogyakarta: UII 
Press, 2019.

Antaranews.com. "Penelitian PKBI Tunjukkan 15\% Remaja

Berhubungan Seks Pra Nikah". https://www.antaranews. com / berita / 49272 / penelitian-pkbi-tunjukkan-15-remajaberhubungan-seks-pra-nikah. Diakses 6/2/2020.

Arief, Barda Nawawi. Tujuan dan Pedoman Pemidanaan. Semarang: Badan Penerbit Magister, 2011.

Atmosudirjo, S. Prajudi. Hukum Administrasi Negara. Jakarta: Ghalia Indonesia, 1994.

Audah, Abdul Qadir. Ensiklopedi Hukum Pidana Islam. Terjemahan Salisah. Jakarta: Kharisma Ilmu, 2007.

Aulia, M. Zulfa. "Friedrich Carl von Savigny tentang Hukum: Hukum sebagai Manifestasi Jiwa Bangsa”. Undang: Jurnal Hukum, 3, 1 (2020): 201-36. DOI: 10.22437/ujh.3.1.201-236.

Bassar, M. Sudrajat. Tindak-Tindak Pidana Tertentu di dalam Kitab Undang-Undang Hukum Pidana. Bandung: Remaja Rosdakarya, 1986.

Black, Henry Campbell, Joseph R. Nollan, dan M.J. Connolly. Black's Law Dictionary. Saint Paul: West Publishing Co., 1979.

Chazawi, Adami. Tindak Pidana mengenai Kesopanan. Jakarta: Raja Grafindo Persada, 2005.

Garner, Bryan A. Black's Law Dictionary. Saint Paul: West Publishing Co., 2004.

Hadikusuma, Hilman. Hukum Pidana Adat. Bandung: Alumni, 1984. Handoko, Bobi, Erdianto Effendi, dan Rahmad Hendra. "Penerapan Sanksi Pidana Adat terhadap Pelaku Zina di Wilayah Kanagerian Garagahan Kecamatan Lubuk Pasung Kabupaten Agam.” https:/ / jom.unri.ac.id/index.php/JOMFHUKUM/article / view/ 5855 .

Handrawan. "Sanksi Adat Delik Perzinaan(Umoapi) dalam Perspektif Hukum Pidana Adat Tolaki”. Perspektif: Kajian Masalah Hukum dan Pembangunan, 21, 3 (2016): 199-210. DOI: 10.30742/ perspektif.v21i3.582.

Harisman, Sabrina Hidayat, dan Handrawan. "Penyelesaian Delik

Perzinahan dalam Hukum Adat Tolaki." Halu Oleo Legal Research, 
1, 1 (2019): 59-75. DOI: $10.33772 /$ holresch.v1i1.6069.

Hiariej, Eddy O.S. Prinsip-Prinsip Hukum Pidana. Yogyakarta: Cahaya Atma Pustaka, 2016.

Hikmawati, Puteri. "Pidana Pengawasan sebagai Pengganti Pidana Bersyarat Menuju Keadilan Restoratif.” Negara Hukum, 7, 1 (2016): 71-88. DOI: 10.22212/jnh.v7i1.923.

Huda, Syamsul. "Zina dalam Perspektif Hukum Islam dan Kitab Undang Undang Hukum Pidana.” Hunafa: Jurnal Studia Islamika, 12, 2, (2015): 377-97. DOI: 10.24239/jsi.v12i2.401.377-397.

Ishak. "Analisis Hukum Islam tentang Perbuatan Zina dalam Pasal 284 KUHP.” Kanun Jurnal Ilmu Hukum, 14, 1 (2012): 165-78.

Kholid Syamhudi. "Hukuman Untuk Pezina". https://almanhaj. or.id/2641-hukuman-untuk-pezina.html. Diakses 11/9/2020.

Kominfo.go.id. "Rata-rata Tiga Orang Meninggal Setiap Jam Akibat Kecelakaan Jalan”. https: / /kominfo.go.id/index.php/content/ detail/ 10368 / rata-rata-tiga-orang-meninggal-setiap-jamakibat-kecelakaan-jalan/0/artikel_gpr, 22/8/2017. Diakses 29/9/2020.

Luthan, Salman. "Asas dan Kriteria Kriminalisasi”. Jurnal Hukum Ius Quia Iustum, 16, 1 (2009): 1-17. DOI: 10.20885/iustum.vol16. iss1.art1.

Mansyur, Zaenudin. "Pembaruan Hukum Islam tentang Empat Saksi Laki-laki Non-Muslim dalam Kasus Li'an”. Al-Manahij: Jurnal Kajian Hukum Islam, 13, 2 (2019): 281-94. DOI: 10.24090/mnh. v13i2.2953.

Mujieb, M. Abdul, Mabruri Tholhah, dan Syafi'ah AM. Kamus Istilah Fiqh. Jakarta: Pustaka Firdaus, 2002.

Muslich, Ahmad Wardi. Hukum Pidana Islam. Jakarta: Sinar Grafika, 2005.

Ridoi, Muhammad, Erdianto, dan Ledy Diana. "Penerapan Pidana Adat dan Pidana KUHP terhadap Pelaku Tindak Pidana Zina Dikaitkan dengan Peran Kepolisian (Studi Kasus di Wilayah Hukum Persukuan Domo Air Tirs dan Polres Kampar)." https: / / jom.unri.ac.id/index.php/JOMFHUKUM/article/view/16571. Rozah, Umi dan Erlyn Indarti. "Delik Zina: Unsur Substansial dan 
Penyelesaiannya dalam Masyarakat Adat Madura." Masalah-Masalah Hukum, 48, 4 (2019): 366-75. DOI: 10.14710/ mmh.48.4.2019.366-375.

Rustamaji, Muhammad. "Biomijuridika: Ilmu Hukum Pidana Berketuhanan dari Barda Nawawi Arief”. Undang: Jurnal Hukum, 2, 1 (2019): 193-223. DOI: 10.22437/ujh.2.1.193-223.

Setiady, Tolip. Intisari Hukum Adat Indonesi. Bandung: Alfabeta, 2009. Sidharta, Bernard Arief. Refleksi tentang Struktur Ilmu Hukum: Sebuah Penelitian tentang Fundasi Kefilsafatan dan Sifat Keilmuan Hukum sebagai Landasan Pengembangan Ilmu Hukum Nasional Indonesia. Bandung: Mandar Maju, 1999.

Soemadiningrat, Otje Salman. Filsafat Hukum (Perkembangan \& Dinamika). Bandung: Rafika Adhitama, 2010.

Soemadiningrat, Otje Salman. Rekonseptualisasi Hukum Adat Kontemporer. Bandung: Alumni, 2011.

Soepomo, R. Bab-Bab tentang Hukum Adat. Jakarta: Pradnya Paramita, 1993.

Soesilo, R. Kitab Undang-Undang Hukum Pidana serta Komentar Komentarnya Lengkap Pasal Demi Pasal. Bogor: Polites, 1996.

Sudiyat, Iman. Hukum Adat Sketsa Asas. Yogyakata: Liberty, 1981. Surya, Hendra, Rusjdi Ali Muhammad, dan Mohd. Din. "Studi Perbandingan tentang Konsep Perzinaan Menurut KUHP dengan Hukum Pidana Islam.” Jurnal Ilmu Hukum, 1, 3 (2013): 75- 83.

Syaikh, Abdullah bin Muhammad Alu. Tafsir Ibnu Katsir: Jilid 5. Terjemahan M. Abdul Goffar. Jakarta: Pustaka Imam Syafii, 2008.

Umar, Nasarudin. "Konsep Hukum Modern: Suatu Perspektif Keindonesiaan, Integrasi Sistem Hukum Agama dan Sistem Hukum Nasional". Walisongo: Jurnal Penelitian Sosial Keagamaan, 22, 1 (2014): 157-80. DOI: 10.21580/ws.22.1.263. 